Int. J. Electrochem. Sci., 14 (2019) $6682-6698$

International Journal of

ELECTROCHEMICAL

SCIENCE

WWW.electrochemsci.org

\title{
Corrosion Inhibition Efficiency of Expired Nitazoxanide Drug on Carbon Steel in Hydrochloric Acid Solution
}

\author{
M. M. Motawea \\ Department of Chemistry, College of Science, University of Bisha, Bisha, Kingdom of Saudi Arabia \\ and Delta Higher Institute of Engineering \& Technology Mansoura, Egypt \\ E-mail: $\underline{\text { dr_mmm_2018@yahoo.com }}$
}

doi: $10.20964 / 2019.07 .25$

Received: 2 March 2019 / Accepted: 18 April 2019 / Published: 10 June 2019

The corrosion inhibition of the expired Nitazoxanide drug was investigated in inhibiting the carbon steel (CS) corrosion in $1 \mathrm{M} \mathrm{HCl}$ using chemical method (weight loss (WL)), two electrochemical test (potentiodynamic polarization (PP) and electrochemical impedance spectroscopy (EIS) techniques) combined with surface analysis. The results show that the expired Nitazoxanide drug are effective and attain their action as mixed type corrosion inhibitors, and their corrosion inhibition affinities were increase with the rising of their concentration and lower temperature. The adsorption of the expired Nitazoxanide drug on the CS surface was obeyed Langmuir isotherm. The adsorption thermodynamic parameters calculated show that the adsorption was a spontaneous, endothermic process accompanied by an increase in the entropy. The maximum data of the inhibition approached to $90 \%$ within the presence of $300 \mathrm{ppm}$ expired Nitazoxanide drug using potentiodynamic polarization process. The results of surface analysis and the electrochemical technique were in a great agreement

Keywords: Acid corrosion, C-steel, SEM, AFM, FTIR, Adsorption, Nitazoxanide drug

\section{$\underline{\text { FULL TEXT }}$}

(C) 2019 The Authors. Published by ESG (www.electrochemsci.org). This article is an open access article distributed under the terms and conditions of the Creative Commons Attribution license (http://creativecommons.org/licenses/by/4.0/). 